\title{
Refuge
}

Canada's Journal on Refugees

Revue canadienne sur les réfugiés

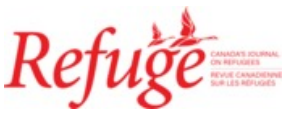

\section{Coercive Transnational Governance and Its Impact on the Settlement Process of Eritrean Refugees in Canada}

\section{Aaron Berhane and Vappu Tyyskä}

Volume 33, Number 2, 2017

URI: https://id.erudit.org/iderudit/1043065ar

DOI: https://doi.org/10.7202/1043065ar

See table of contents

Publisher(s)

Centre for Refugee Studies, York University

ISSN

0229-5113 (print)

1920-7336 (digital)

Explore this journal

Cite this article

Berhane, A. \& Tyyskä, V. (2017). Coercive Transnational Governance and Its Impact on the Settlement Process of Eritrean Refugees in Canada. Refuge, 33(2), 78-87. https://doi.org/10.7202/1043065ar
Article abstract

This article will examine the transnational practices of the Eritrean government, and their impact on the settlement of Eritrean refugees in Canada. The focus is on actions by the Eritrean regime that have a negative effect on refugees' capacities for successful integration, and undermine Canadian sovereignty. The concept of coercive transnational governance (CTG) is introduced, to highlight this neglected aspect of refugee resettlement, with illustrations from 11 interviews, including eight Eritrean refugees, one Eritrean community activist, and two Canadian law enforcement officers, about the impact of CTG on Eritrean refugees' lives.
Copyright (c) Refuge: Canada's Journal on Refugees, 2017

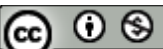

This document is protected by copyright law. Use of the services of Érudit (including reproduction) is subject to its terms and conditions, which can be viewed online.

https://apropos.erudit.org/en/users/policy-on-use/ 


\title{
Coercive Transnational Governance and Its Impact on the Settlement Process of Eritrean Refugees in Canada
}

\author{
AARON BERHANE AND VAPPU TYYSKÄ ${ }^{1}$
}

\section{Abstract}

This article will examine the transnational practices of the Eritrean government, and their impact on the settlement of Eritrean refugees in Canada. The focus is on actions by the Eritrean regime that have a negative effect on refugees' capacities for successful integration, and undermine Canadian sovereignty. The concept of coercive transnational governance (CTG) is introduced, to highlight this neglected aspect of refugee resettlement, with illustrations from 11 interviews, including eight Eritrean refugees, one Eritrean community activist, and two Canadian law enforcement officers, about the impact of CTG on Eritrean refugees' lives.

\section{Résumé}

Cet article examine les pratiques transnationales du gouvernement d'Érythrée et leurs conséquences sur létablissement de réfugiés érythréens au Canada. Il est centré sur les actions du régime érythréen qui ont des conséquences négatives sur les capacités des réfugiés à réussir leur intégration et affaiblissent la souveraineté canadienne. Pour souligner cette perspective négligée de la réinstallation des réfugiés, il introduit le concept de Gouvernance transnationale coercitive (GTC), qu'il illustre à l'aide de 11 entretiens, parmi lesquels huit entretiens avec des réfugiés érythréens, un entretien avec un activiste de la communauté érythréenne, et deux entretiens avec des agents canadiens chargés de l'application de la loi, et il envisage les répercussions de la GTC sur la vie des réfugiés érythréens.

\section{Introduction}

7 anada has been a safe haven for thousands of refugees who have fled dictatorial regimes in their home countries. It is in the interest of the Canadian government to create a secure system to protect refugees and ensure that their integration process moves smoothly, and that they overcome their challenges. While language barriers, unemployment, and lack of recognition of international credentials are the most-discussed obstacles to refugees' integration, the security challenges facing refugees have not received the attention they deserve. Intimidation, threats, and surveillance of refugees are some of them. ${ }^{2}$ They put the peace and mental stability of some refugees at risk and delay their integration. The case of Eritrean migrants is a good example. This focus on Canada is particularly important, given the official critical position of the Canadian government toward the current Eritrean government, expressed in its support for the United Nations Security Council sanctions toward Eritrea, and Resolution 2023 (2011), for Eritrea to "cease using threats of violence, fraud and other illicit means to collect taxes outside of Eritrea."3 This affirmation to uphold international decrees also calls for attention to the conditions for refugees who have been granted asylum in Canada.

Eritreans have been dispersed from their home country as a result of colonial aggression from 1890 to 1991, and the struggle against Ethiopia from 1961 to 1991, which contributed to the emigration of more than half a million people. 4 The resettlement of Eritreans in Canada started in the early $19800^{5}$ and continued to grow after Eritrea became 
independent. They, like many African immigrants, have experienced challenges during their settlement process, including discrimination in accessing employment, finding a place to live, and mastering the official languages. ${ }^{6}$ However, their settlement experience is unique because their challenges come not only from the host society but also from the government of their home country. Additionally, while the literature on Eritrean transnationalism is focused on the conditions in Eritrea itself, 7 our research brings a missing element in addressing the conditions of settlement in countries of arrival.

\section{Transnational Governance}

The term transnational governance became prominent in the twentieth century before the world grasped the change as an alternative to globalization. According to Djelic and SahlinAndersson, the words do not convey the same meaning: globalization is used to describe the activities done across geographical borders, while transnational governance is an integral part of geopolitical administration and the practices of a number of global institutions. ${ }^{8}$ In sum, "Governance beyond the nation state means creating political order in the absence of a state with a legitimate monopoly over the use of force and the capacity to enforce the law and other rules authoritatively."9 It includes the ways a government governs its citizens beyond the geographic boundaries of its jurisdiction. However, this should not imply the "disappearance of nation-states," ${ }^{10}$ or the undermining of international institutions that govern their activities without the interference of the states, ${ }^{11}$ though it can erode territorial boundaries and blur standard regulations.

With the expansion of transnationalism, a number of regulations emerged globally. Baldwin, Scott, and Hood categorize three types of regulations: authoritative rules, efforts to steer the economy, and means of social control. ${ }^{12}$ Therefore transnational regulation as a concept is a form of "governance in the sense that it structures, guides and controls human and social activities and interactions beyond, across and within national territories." 13 Such practices are documented, e.g., for Haiti. ${ }^{14}$ Some authoritarian countries, usually with high emigration, apply a diverse range of mechanisms to engage their diasporas for financial extraction. ${ }^{15}$ In Eritrea, the government retaliates against the families of exiled members by forcing them to pay a fine or face time in prison, and uses its institutions abroad to maintain political control and governance through fear from a distance. ${ }^{16}$ Or as Hepner articulates it, the Eritrean government interferes aggressively in the life of the Eritrean diaspora to be in command of their transnational activities. ${ }^{17}$ While coercive practices are documented in other countries, and there has been scant media attention to the issue, ours is the first Canadian study to rely on interviews of Eritrean refugees about their experiences of transnational governance.

In the era of transnationalism, Aihwa Ong articulates the capacity of the nation-state to control its citizens wherever they are by using law, economy, and social apparatuses. ${ }^{18}$ For instance, some countries sign bilateral tax agreements and they cooperate with each other in taxing their citizens who live abroad. Such agreements can prevent citizens from double taxation ${ }^{19}$ or eliminate tax competition. ${ }^{20}$ This type of transnational governance is done with the common understanding of both parties, and it may not create discomfort for their citizens.

To build on these analyses, we are introducing the new concept of coercive transnational governance (CTG) to describe what is practised outside of bilateral or multinational agreements without the knowledge of any other governments. CTG is a form of governance used by dictatorial regimes to maintain political control and secure financial contributions by force from their citizens who settled in the Western world as refugees. Refugee-sending countries practise CTGto exploit the wealth and resources of their transnational citizens through force or providing mandatory incentives to obtain necessary documents and to ensure the safety of family members still living in or attempting to leave the sending country. стя has exacerbated the settlement challenges of Eritrean-Canadians for over a decade.

Indeed, the literature describes how the Eritrean state uses its transnational institutions not to cultivate the sociopolitical activities of its people or to enable their influence in the foreign world, but to restrict their activities, control their influence, and make them obedient to the regime. ${ }^{21}$

The Eritrean regime suppresses basic human rights and liberties by restricting travel and prohibiting political opposition, independent media, faith groups, or community organizations inside its borders. ${ }^{22}$ Additionally, the Eritrean state controls the lives of its citizens outside the country by installing undercover representatives in every community event, gathering, or association, ${ }^{23}$ creating a "climate of fear." ${ }^{24}$ Significantly, Eritrean embassy and consulate officials in European and North American countries collect an involuntary 2 per cent income tax from Eritreans who work abroad, ${ }^{25}$ described as a "rehabilitation and recovery tax" (mehwey gibri). ${ }^{26}$ Such payments also affect the Eritreans who work in Middle Eastern countries, as they are required to have a valid passport to get a work permit. ${ }^{27}$ The Eritrean government takes advantage of the situation and dictates that they must not only pay the 2 per cent tax, but also donate money to the Hidri Trust Fund ${ }^{28}$ (which is owned by the ruling party) in order to obtain a passport. Those people have no other option(s); their residency in countries like Saudi Arabia depends on having a work permit, but the 
governments of Middle Eastern countries do not interfere in the business of the Eritrean government, even though they know how the Eritrean government exploits its citizens inside their countries.

That is not an issue in Canada, but still the only office that represents the Eritrean government in Canada, the Eritrean consulate, uses extortion, threats of violence, and other illegal means to collect the 2 per cent income taxes from Eritrean-Canadians. Most are forced to pay because the government will not honour their request for passports or any other vital documents that can assist them to obtain permanent resident status in Canada. Even those who do not request any documents and refuse to pay the 2 per cent income tax are intimidated by agents of the regime. These immigrants are warned to do it for the sake of their families in Eritrea. ${ }^{29}$ Eritrean refugees who have not paid the tax have experienced obstacles in sponsoring their family members from their home country, ${ }^{30}$ or in obtaining educational documentation. ${ }^{31}$ Hundreds of millions of dollars are extorted each year in this way and are estimated to amount to $30-35$ per cent of the GDP of Eritrea. ${ }^{32}$

Those who pay the tax violate international and Canadian laws that prohibit monetary assistance to support military activities. ${ }^{33}$ In May 2013, following years of complaints from members of the Eritrean community, the consul general of Eritrea was expelled after he ignored Canada's warning to stop soliciting money from the Eritrean diaspora for military and other purposes. ${ }^{34}$

\section{Background to Eritrean Migrant and Refugee Flows}

Eritrea was a colony of Italy, Britain, and Ethiopia from 1890 to 1991 and experienced large-scale emigration by opponents of colonial rule..$^{35}$ As a result, about one-fourth of Eritrea's six million people still live in exile. After Eritrea's independence in 1991, the number of people who fled the country increased in response to gross human rights violations, forced labour, brutal administration, and a system of "ruthless repression" and "pervasive state control." 36 During the 30-year revolutionary struggle of the Eritrean People's Liberation Front (EPLF) from 1961 to 1991, about one million people escaped and ended up in refugee camps or were prevented from returning home. ${ }^{37}$

The Eritrean diaspora in Canada began in the late 1970s to early 1980 s. $^{38}$ Wherever they settled, Eritrean refugees were organized and mobilized by the EPLF to play their part in the ongoing struggle for independence of their country. During those years the EPLF expanded its activities as a social and political organization among Eritreans abroad, organized the diasporas into chapters of the EPLF, and used its mass associations to channel and manage their support in the revolution. 39
Migration slowed after Eritrea became independent in 1991, but the eruption of border conflicts with Ethiopia from 1998 to 2000 and political instability throughout the country forced many citizens to flee. According to the 2013 report of UNHCR, about 4,00o Eritreans flee the country every month to escape merciless repression, persecution, and forced labour.

Eritrea is a leading producer of refugees. ${ }^{\circ}$ There are no accurate data on Eritrean populations in host countries in North America and Europe, ${ }^{41}$ mostly because during registration they have been classified as "Ethiopians" instead of "Eritreans," since most of them left the country before Eritrea's independence in $1991 .{ }^{42}$ According to the 2011 Household Survey, 13,430 people reported Eritrean ancestry. ${ }^{43}$ However, according to community leaders, about 30,00o Eritreans live in Canada, the majority of them in Ontario.

\section{Research Design}

Having identified and named the practice of coercive transnational governance (СтG), this article aims to investigate its impact on the settlement process of Eritreans in Canada. The goal was to conduct a pilot project, identifying themes for a future, larger-scale analysis. The project was unfunded, limiting the sample size and the generalizability of the data.

Using maximum variation sampling, 44 eight Eritrean refugees were recruited because they currently dealt or had dealt with the Eritrean consulate for services. Six of the refugee participants were men and two were women. Four participants were married and the rest were single during their encounter with the Eritrean consulate. There is variation in the types of services they requested. Additional recruits included one human rights activist who has been vocal about the issue for a number of years, and two law enforcement authorities were also recruited for the relevance of their work in deterring organized crime.

The recruitment poster for this research was circulated among the email group and Facebook page of the Eritrean community, and posters were distributed in Eritrean restaurants in Toronto. Moreover, a letter of invitation to participate in the study was sent via email to 95 members of the primary investigator's network. Participants' desire to share their personal experience was overwhelming. No coercion was used. Eleven participants agreed and gave their written consent for the interview and audio-recording, and the interviews were conducted accordingly.

This study posed semi-structured, open-ended questions about (1) challenges of Eritrean refugees in the settlement process; (2) activities of the Eritrean consulate within the expatriate community; and (3) access to local law enforcement authorities in response to CTG actions of the consulate. The eight Eritrean participants were asked about their 
resettlement experiences; the role of the Eritrean consulate in Toronto in their lives; the services requested or acquired from the consulate; the harassment or intimidation they experienced; whether they reported to police about coercion of the consulate; and recommendations on how to address/ solve this issue. The interview with the human rights activist focused on capturing his perspective on the obstacles facing Eritrean refugees during resettlement; the role of the Eritrean consulate in the life of Eritrean refugees; and whether the activist had attempted to disclose the problem and the challenges they face.

Since there is very little literature on the challenges of Eritrean refugees in Canada, and many of them do not share openly out of fear, a one-to-one interview with refugees is crucial to capturing the essence of their lived experiences. The participants were proficient in English, but the interviews were conducted in English or Tigrigna (whichever the participant chose). Most participants responded to the interview questions in writing, but follow-up questions were answered on the phone and audiotaped, with the participants' consent. 45 Each lasted 15 to 25 minutes and was conducted between August and October 2015. Those eight participants arrived in Canada from 1999 to 2008. Five had issues with Eritrean CTG in obtaining exit visas for their family to reunite with them; two refugees had problems in renewing their expired passports, while the rest had difficulties in acquiring educational documents from Eritrea. In reporting the results, pseudonyms are used, to protect the identity of participants.

The results were analyzed using thematic coding, ${ }^{46}$ identifying commonalities, differences, and relationships between sets of concepts and ideas. ${ }^{47}$ Specifically, themes were formulated with a "prior-research driven method" 48 arising from literature.

\section{Research Findings}

Given the small size of the sample, it was not possible to make conclusions about variation in responses in relation to their demographic differences such as gender, age, or length of stay in Canada.

The interviews show that the readiness of the receiving society to accept refugees is crucial in determining whether those refugees will "sink or swim." 49 If they encounter obstacles in the initial stages of their settlement, their integration could be hindered..$^{\circ}$ Many of the participants reported challenges with getting refugee status or finding employment. However, most participants described the actions of their own government as the biggest barrier in their lives, through denial of passport renewals, exit visas to family members, birth certificates or original education documents, and interference in local community life. In the interviews, CTG was clearly found to create obstacles to Eritrean integration.
They reported difficulties with their (1) finances and education, and (2) family reunification, while they also (3) lived in fear and isolation, and (4) had issues reporting CTG abuses to authorities.

\section{Problems with Employment and Education}

The community activist asserted that educational futures of refugees were seriously affected by inaccessibility to educational documents. Aida, a refugee woman who had arrived in Canada in 2004, told of how her plan to pursue higher education was delayed for about four years as a result of the obstacles of the Eritrean consulate in Toronto: "I was denied access to my own documents that I had worked hard for and earned."

Even with educational credentials, refugees have more difficulties accessing affordable places to live in and finding well-paying jobs. As a result, their income is low and their stress level is high. They struggle to make ends meet for themselves "while sending provision abroad to support family members who have been left behind." 51 They are not only exposed to the common challenges of refugees in creating a secure income but are also forced to pay 2 per cent of their income to the Eritrean regime. This breaks the financial backbone of many refugees at the very beginning.

Samuel, who has been in Canada since 2007, was asked to pay 2 per cent of his income and other fees to get his educational documents from the University of Asmara. He said, "In general, I paid around $\$ 1,000$ for the 2 per cent tax. Moreover, I didn't have a stable job. As a newcomer, you don't have any savings. Yet, you have to cover the grocery, rent, and everything you need for the baby. It was not easy."

The activist provided an example of one refugee he assisted:

There was one Eritrean who came to Canada as a governmentsponsored refugee from a prison in Egypt. This guy left his wife and three children behind. He was getting some support from the Canadian government ... At the time when he was trying to bring his children and his wife, he was asked to pay the 2 per cent tax. When the calculation of the 2 per cent tax came, even the time he had spent in Egypt was taken into consideration ... To me, it is nonsense.

The second thing is at that time he himself was dependent on the Canadian government. In other words, your money and my money as taxpayers were taken away by the consulate. That's what surprised me.

Russom, who claimed asylum in 2001 and has lived in Canada since then, described his struggle elegantly. What surprised him most about the behaviour of the Eritrean consulate was their lack of consideration for disabled people 
and individuals who live on social welfare. The office forced everyone to pay, regardless of the individuals' situations. He stated, "I was helping myself because I didn't have anyone to cook and clean my house, everything. So my cost was doubled like everyone else. They didn't even consider my personal challenges as a disabled person. The consulate was looking after my money, not after me as a person or a citizen." He was charged $\$ 5$ a month for the two years (2001-3) when he was on social welfare and 2 per cent of his income for the few months that he had worked. "I know there are people who paid over $\$ 5,000$ or $\$ 6,000$ from their income. I was so lucky. My damage was not too much but still it was not legal."

The inability to pay the extorted fees also creates difficulties for mobility, further hindering people's capacity to conduct their regular lives. Feruz, who left Eritrea legally to reunite with her family in Canada in 2010, was denied renewal of her passport, simply because she rebuffed the 2 per cent tax: "So I applied to the Canadian government for a travel document. I explained to them that the Eritrean government refused to renew my passport unless I paid the 2 per cent tax on my income. Then they asked me to present a written legal document from the Eritrean government, saying that they had refused to renew my passport because of that. However, the Eritrean consulate didn't want to give me a written document, and the Canadian government didn't understand. It was very challenging.

This obstacles can be endured only by determined refugees who know how the system works-like Feruz-or refugees who are willing to pay the price. The lack of understanding by Canadian government departments of how the Eritrean regime mistreats refugees throws many newcomers into a suffocating situation. As a result, Eritrean refugees feel helpless and sometimes are forced to break Canadian law to fulfil requests by the Eritrean consulate to donate money for military activities, which is illegal under Canadian law (this payment would be in addition to the 2 per cent tax on income). This puts at stake the safety of refugees as well as the sovereignty of Canada. As long as the Canadian government's policy is not tailored to address the Eritrean refugees' issues separately, their misery will continue and Canadian law will be challenged.

\section{Problems with Family Reunification}

One major issue facing refugees is reuniting with family members they had to leave behind. This is seriously impaired by CTG. The activist disclosed that a refugee whom he was assisting was forced to pay $\$ 10,000$ to the Eritrean Consulate to secure an exit visa for his wife. "If that money were here, that person could have used that money to invest in building his skills or use it as a down payment for his home, which takes him away from being a burden to Canadian society. Or the money can also be used for the Canadian community, for that matter. So, you see the impact is so great."

Most participants were separated from their loved ones for a number of years. For the sake of their families and their loved ones who lived in the grip of the Eritrean regime, three participants fulfilled the demands of the consulate. They paid 2 percent of their annual income and donated money to military defence to get exit visas for their family and secure their educational documents from Eritrea.

Some refugees get exit visas for their family after their payments to the Eritrean regime. However, many participants believe that that does not work for everyone. They do not receive any guarantee from the Eritrean regime. The interviewees spoke of the risks they were forced to take, to get their families out of Eritrea by human smugglers, a physically and psychologically stressful, expensive, and dangerous enterprise. Yohannes entered Canada in 2008 and claimed for refugee status inland. He said, "In the last eight years that I have stayed here, I have spent more money to pay for their escape than what I spent to feed them while they were in Eritrea. You are forced to spend your four-year income for such a purpose because there is no other choice. It drains you financially and leaves you without any money. I was forced to pay us $\$ 20,000$ to the smugglers."

The experience of Belay is similar. He came in 2006, leaving his family behind, and claimed refugee status when he entered Canada. He had just finished his graduate studies and began working on contract. Despite his dire financial situation, he had to do anything to reunite with his family before things got worse in Eritrea. He noted, "I didn't have enough money to meet all my financial needs. So, what I did, I had to ask my friends and relatives for credit because I can't finance it with my credit card. I have to have cash, so I have to rely on friends and relatives who wish to reunite me with my family." He reunited with his family after four years of separation. Still, he could have paid off his student debt and gotten better housing if he wasn't forced to spend it on getting his family to join him. The tremendous amount of money that refugees are forced to pay the Eritrean consulate or smugglers to unite with their family is a real drain on their resources. This money could have been used to ease their financial challenges instead.

In 2015, after the Eritrean consulate had refused to assist Yohannes unless he paid the 2 per cent tax on his income. He noted, "When I decided to bring my family out, I just took a 50 percent chance, either to smuggle them successfully or lose them. There are soldiers who patrol the border day and night. If the smugglers try to smuggle them out while the army is on duty, they can be killed. The other thing is the issue of smugglers. You have no idea whether they are independent or whether they work for the government. So they 
can take your money and not bring your family or they can sell them to other smugglers. The risks are huge."

Likewise, Belay spoke of the dangers that threatens his psychological state: "The whole process was psychologically traumatic both for my family and me. The effect has longterm consequences. I was in a constant state of psychological turmoil and stress, which lasted for a very long time. In fact, it can affect not just your health and psychological wellbeing, but also that of your family."

The risks these refugees took to reunite with their family are enormous. They put the lives of their loved ones in great danger to secure their ultimate safety. There was no guarantee of finding a safe way to escape from Eritrea, but that was the only option they believed they had. In the process, they were prepared to suffer psychologically, become broke financially, and pay any price to bring their family and restart their life in Canada. Unfortunately, the path of restarting a new life is not easy for most, as a result of the psychological trauma they experience as a result of tackling such great odds.

\section{Fear and Isolation}

Participants expressed a number of fears: safety of family members in Eritrea; safety of their passage to Canada; and the threatening presence of СтG in their lives in Canada, through the acts of the consulate and suspected community collaborators.

All participants believe that any activity they engage in Canada can negatively affect the fate of their family. They do not feel free or secure to reject or criticize the demands of the Eritrean consulate in Toronto, despite the protection they are provided by the Canadian government. The words of Yohannes are typical and reflect the isolation that results from mutual suspicion generated by the fear: "The office asks every individual to pay the 2 per cent tax, donate money, and the worst thing is the fear they have instilled in many Eritreans who live here. This makes all Eritreans suspicious of one another." Russom stated that the main targets of the consulate are refugees: "They were taking advantage of refugees, especially refugees because they know that we have left people we love behind ... I cannot oppose what the Consulate is doing." As a result of this threat, many Eritrean refugees live in a state of fear for their family members who still live in Eritrea. Since those refugees do not know how the system can protect them, they censor their conversations and activities and restrain themselves from complaining to Canadian law enforcement agencies for fear of retaliation to their loved ones by the Eritrean government. Even though they live in a presumably free and democratic society, they do not feel liberated.
The fear and intimidation of the Eritrean regime are pervasive. Feruz immigrated to Canada in 2010 to join her family. She said, "They threaten the people not to express their voice against the Eritrean government and force them to pay 2 per cent of their income."

Samuel, a refugee in Canada since 2007, consolidated Feruz's points by sharing his own story in the second week of his arrival. He was invited to attend a meeting in the church and was disturbed by what he heard: "The guest speaker was ... the Eritrean consul. His speech gave me nightmares about the brutality of the Eritrean regime. It continues even here. When I left the meeting, I cried all the way home. What he was saying was that everyone has to be up-to-date in paying the 2 per cent tax, and every household has to pay $\$ 500$ to fund the Eritrean defence forces." Samuel said that the Eritrean consulate interfered in the business of the community centre that provides settlement services to newcomers:

The concern I have with the consulate is that they mix their consular business with the community groups, which are supposed to be non-partisan and non-divisive, focusing on the settlement needs of newcomers. To Canadians, the Canadian government, and the media, these groups look like communities from outside, but they are politically polarized; they use different tactics in isolating people who speak up about what happened to them under the regime. The consulate also spreads rumours to scare and control others who might follow the same path. They use scare tactics to threaten to retaliate against family and refuse to provide services that are meant for all newcomers. Instead, they only assist those who are loyal to the regime.

Front and centre of those refugees' fear is their loved ones. They do not want their family members to be punished by the Eritrean government for disobeying the Eritrean consulate in Canada. They do not want their issues to end up in the public domain so that the Eritrean regime could retaliate against their loved ones. Those refugees do not see a shield of Canadian police that can protect them from this coercive transnational governance.

Refugees' fears were compounded by the resultant isolation. What prevents most Eritrean refugees from reporting their complaints to Canadian law enforcement agents is fear of repercussions. They are afraid to testify or act as witnesses for the police because of their loved ones who live in their country of origin. Refugees say that their family members can be tortured, arrested, or forced to pay hefty money as a reprisal. Meanwhile, Canadian law enforcement agents will always need the cooperation of the victims to push cases forward and resolve issues. Agents may guarantee the safety of refugees in their jurisdiction, but not their families who 
live outside Canada. Participants in this research know this and that is why they do not come forward to seek help. So they will remain fearful and isolated victims of CTG until the Canadian law enforcement agents figure out how to handle it.

\section{Problems with Reporting CTG to Authorities}

There is great lack of trust in the way police work in less developed and post-authoritarian countries. ${ }^{52}$ Immigrants who came from those regions tend to distrust police after their previous bad experiences and may not initially approach police for help. However, this was not an issue for the participants in this research. Instead, five participants did not seek help or file complaints with Canadian law enforcement agents out of fear of retaliation on their loved ones by the Eritrean regime. Ghebru, who found his way to Canada via the United States to claim asylum in 2008 said, "I and many others prefer to keep quiet because, for any action that is taken by me or someone like me here, our parents will eventually pay the price. They will get detained and have to pay a hefty amount of money. This is practised widely in Eritrea and, unfortunately, for that reason, many who have loved ones in Eritrea prefer to keep silent."

The police officers interviewed declared that matters can be handled confidentially, although one of them also noted that victims would need further assistance to push cases forward. He noted, "Your complaints are a confidential matter between you and the police. If you complain about someone who is intimidating you and harassing you, the police can go to them to hear that person's side of their story too. We realize it is a difficult situation. The best thing to do in these circumstances is to take notes about what happened to you, why you think it happened, who did it, and present that to the police. You can go to any police station in Toronto."

Belay noted that in addition to fear, lack of knowledge of the Canadian system could be an issue for some refugees, a sentiment that was echoed by the community activist: "The problem lies with the mentality of some of our people. So far, they haven't been really liberated, partly because some of them do not know that the law exists to protect them."

However, three refugees had taken their issues to the RCMP and police, but they were not always happy with the results. Russom reported his experiences to a police station, only to stop his case because he was told that they could do nothing because he had not been "forced to pay." This suggests that the way the RCMP or police handle the complaints may discourage Eritrean refugees from coming forward. Neither officer interviewed could talk about specific issues and instead pointed to standard procedures. How informed are police about the transnational nature of community politics, harassment, intimidation, and the controversial fundraising activities? As the demography of the country changes rapidly as well as the nature of crimes, law enforcement officers may have some catching up to do to deal with immigrants' issues.

To simplify the way refugees report their concerns or file their complaints, it is crucial to have a specific unit or at least contact persons in the law enforcement agencies who understand the complexities of the refugees' issues. Otherwise, refugees will keep suffering because law enforcement agents do not understand their issues. Most of all, the CTG will keep undermining Canadian law by imposing rules on citizens of Eritrean origin. Those refugees are forced to donate money for Eritrean military activities, despite the fact that it is illegal in Canada. The actions of the Eritrean regime violate international law, undermining Canadian sovereignty, and worst of all, committing crimes against helpless refugees. This cannot be resolved by the local law enforcement agents, but by addressing the issue on the higher level-senior officials of the Canadian government with senior officials of the Eritrean government.

\section{Conclusion and Recommendations}

Canada has become home for thousands of Eritrean refugees who were forced to leave their country of origin because of war, colonialism, and political instability. Eritrean refugees face obstacles during their settlement process in Canada, including the language barrier, financial challenges, discrimination, and lack of employment. However, to make matters worse, unlike other African immigrants, their journey to a new life in Canada is jeopardized because of the coercive transnational governance of their home country. This new term was coined to accurately describe a practice that has been identified by other researchers regarding Eritrean regime.

In addition to contributing to the terminology of the subject matter, this article also aims to illustrate the impact of СтG on refugees' lives. Eleven people were recruited for this research, including eight Eritrean refugees who arrived in Canada in the last 20 years, one community activist, and two law enforcement officers.

The findings clearly confirm the issues raised regarding the role of the Eritrean regime in controlling the lives of its people in diaspora, while giving a voice to the refugees themselves about the impact of those acts. The Eritrean consulate in Toronto creates insurmountable hurdles for Eritrean refugees in the initial stages of their settlement by instilling fear, by dangling its consular services for a payment of 2 per cent income tax and drying up the financial resources of Eritrean refugees. The participants shared a rocky transition to a new life. Their personal lives are put on hold by withdrawal of documents that they could use to establish a better start or to enjoy mobility to tend to their affairs. Their family lives are on hold as well, with many risking the dangers of human smuggling when the 
exit visas of spouses and children from Eritrea are refused. The monetary and psychological costs that arise from these stresses created by the Eritrean regime are enormous.

One major barrier that all participants experienced during their settlement process was fear instilled by the Eritrean consulate, which effectively silenced the refugees' critical voices, because the consulate interfered and spied upon their activities and punished family members of any exiled person who spoke against the Eritrean government. Despite the presumed protection granted by the Canadian government, participants lived in constant fear of the regime that was trying to govern them from afar. Fear for the lives of family members prevents refugees from contacting Canadian law enforcement bodies, and those who do are frustrated by the unhelpful responses that further discourage people from coming forward.

The findings reveal that the Eritrean consulate is the cause of the rough transition and integration process of Eritrean refugees in Canada. Our research demonstrates that the consulate uses the facade of a legal office to interfere in the settlement and integration process of refugees by applying coercive transnational governance and undermining Canadian law. This undermines Canadian sovereignty, as the consulate dictates the lives of Eritrean refugees who will become Canadian citizens. Since the notion of a sovereign state is the freedom from interference by foreign sources or powers, the coercive transnational practices of the Eritrean government and businesses pose a challenge to Canadian sovereignty, interfering with the lives on its soil, of a group of people who are either citizens or future citizens. The government of Canada respects Eritrean sovereignty while objecting to-but not interfering with-matters internal to Eritrea. This is an unbalanced relationship in which Canada's government has to take charge to re-establish its sovereignty by putting a stop to unacceptable and illegal acts that jeopardize its population.

\section{Recommendations}

Several major issues and associated recommendations result from this study to alleviate the challenges of Eritrean refugees and secure Canadian sovereignty. Although the sample of this study is small, the refugees' experiences analyzed here suggest specific issues and point to possible solutions:

1. The major issue is that Eritrean refugees face financial decimation and general hardship in their lives, due to the payments demanded by representatives of the Eritrean government in their countries of exile. As a solution, a specific unit or at least a contact person could be designated by the Canadian government that allows refugees to file their complaints easily whenever they are threatened, receive demands to pay money, or are ordered to become involved in activities against their will by the government of their home country or its representatives.

2. A related issue is that Eritrean refugees feel threatened by their former country of origin, do not feel that they are protected by Canadian government officials, and do not know who to turn to when they have difficulties with the Eritrean government and its representatives. There are a number of areas where this issue needs to be addressed:

- The primary area is the need for government action. The Canadian government must address the concerns of Canadian citizens of Eritrean origin with the Eritrean government on a higher level and end the practice of the regime that undermines Canadian sovereignty and threatens citizens' safety. These complaints and concerns should also be officially conveyed at the international level, to the United Nations High Commissioner for Refugees.

- A related issue is the education of newcomers about their rights and duties in Canada, and how the law enforcement agents operate to protect them. A related point is that those who are victimized by CTG should be given specific protection, to encourage them to come forward to make complaints.

- Similarly, community service agencies and law enforcement agents should be educated about the specific needs and complex challenges of the refugee populations they serve. In this area, they should be made aware of the oppressive practices of dictatorial regimes and their use of consulate offices or individuals.

3. A further area of concern is lack of knowledge about the specific coercive practices of oppressive regimes against their former citizens abroad. To this end, there is need to promote and fund research on coercive transnational governance and experiences of certain groups of nationalities. Our small-scale study highlights the need to listen to the experiences of refugees and to follow up with larger-scale studies to identify and address their challenges. It is only by expanding this knowledge base that governments, community organizations, and law enforcement agencies can be convinced of the needs of specific refugee populations. Further research is needed on Eritrean and other populations facing CTG, to establish the prevalence of these different practices, and their consequences on the populations, including impacts on individuals and families.

\section{Notes}

1 We are thankful for the comments provided by Idil Atak and Myer Siemiatycki on earlier drafts of this article. We 
also thank the anonymous reviewers for their constructive comments.

2 Canadian Council for Refugees, "Request for Suspension of Removals to Eritrea," December 2016, http://ccrweb.ca/ sites/ccrweb.ca/files/eritrea-submission-2016.pdf.

3 Embassy of Canada to Sudan, "Canada-Eritrea Relations," July 2014, http://www.canadainternational.gc.ca/sudansoudan/bilateral_relations_bilaterales/eritrea-erythree. aspx?lang=eng.

4 Tricia R. Hepner, "Transnational Governance and the Centralization of State Power in Eritrea and Exile," Ethnic and Racial Studies 31, no. 3 (2008): 476-502.

5 Kisanet Tezare, Tsehay Said, Daniel Baheta, Helen Tewolde, and Amanuel Melles, The Role of the Eritrean Diaspora in Peacebuilding and Development: Challenges and Opportunities (Toronto: Walter and Duncan Gordon Foundation, 2006).

6 Ibid.

7 David Bozzini, "The Fines and the Spies: Fears of State Surveillance in Eritrea and in the Diaspora," Social Analysis 59, no. 4 (2015): 32-49.

8 Marie-Laure Djelic and Kerstin Sahlin-Andersson, "Transnational Governance in the Making: Regulatory Fields and Their Dynamics," Transnational Governance: Institutional Dynamics of Regulation (2006): 1-47.

9 Thomas Risse, "Transnational Governance and Legitimacy," in Governance and Democracy: Comparing National, European and International Experiences, ed. Arthur Benz and Yannis Papadopoulos (New York: Routledge, 2006), 179.

10 Peter J. Katzenstein, Robert O. Keohane, and Stephen D. Krasner, "International Organization and the Study of World Politics," International Organization 52, no. 4 (1998): 645-85; and Djelic and Sahlin-Andersson, "Transnational Governance in the Making."

11 Thomas Risse, "Transnational Governance and Legitimacy."

12 Robert Baldwin, Colin Scott, and Christopher Hood, A Reader on Regulation (London: Oxford University Press, 1998).

13 Djelic and Sahlin-Andersson, "Transnational Governance in the Making," 8.

14 Michel S. Laguerre, "State, Diaspora, and Transnational Politics: Haiti Reconceptualised," Millennium: Journal of International Studies 28, no. 3 (1999): 633-51; and José Itzigsohn, "Immigration and the Boundaries of Citizenship: The Institutions of Immigrants' Political Transnationalism," International Migration Review 34, no. 4 (2000): 1126-54.

15 Itzigsohn, "Immigration and the Boundaries of Citizenship."

16 Bozzini, "Fines and the Spies."

17 Tricia M. Redeker Hepner, Soldiers, Martyrs, Traitors, and Exiles: Political Conflict in Eritrea and the Diaspora (Philadelphia: University of Pennsylvania Press, 2009).

18 Aihwa Ong, Flexible Citizenship: The Cultural Logics of Transnationality (Durham, NC: Duke University Press, 1999).
19 Bruce A. Blonigen and Ronald B. Davies, "The Effects of Bilateral Tax Treaties on Us FDI Activity," International Tax and Public Finance 11, no. 5 (2004): 601-22.

20 Richard Chisik and Ronald B. Davies, "Asymmetric FDI and Tax-Treaty Bargaining: Theory and Evidence," Journal of Public Economics 88, no. 6 (2004): 1119-48.

21 Nadje Al-Ali, Richard Black, and Khalid Koser, "The Limits to 'Transnationalism': Bosnian and Eritrean Refugees in Europe as Emerging Transnational Communities," Ethnic and Racial Studies 24, no. 4 (2001): 578-60o; and Tricia Redeker Hepner, "Religion, Nationalism, and Transnational Civil Society in the Eritrean Diaspora," Identities: Global Studies in Culture and Power 10, no. 3 (2003): 269-93.

22 Amnesty International, Amnesty International Report 2014/15: The State of the World's Human Rights, https://www. amnestyusa.org/pdfs/AIR15_English.PDF, 145.

23 Hepner, "Transnational Governance."

24 Eric Popkin, "Transnational Migration and Development in Postwar Peripheral States: An Examination of Guatemalan and Salvadoran State Linkages with Their Migrant Populations in Los Angeles," Current Sociology 51, nos. 3-4 (2003): 369.

25 Samia Tecle, "The Paradoxes of State-Led Transnationalism: Capturing Continuity, Change and Rupture in the Eritrean Transnational Social Field" (mA diss., York University, 2012), 25.

26 Independent Advisory Group on Country Information, "Country Information and Guidance Eritrea: Illegal Exit," 1 September 2015, https://www.gov.uk/government/uploads/ system/uploads/attachment_data/file/459486/Eritrea_-Illegal_Exit___v2_oe.pdf.

27 Nicole Hirt, "The Eritrean Diaspora: Savior or Gravedigger of the Regime? Diaspora Responses to the Imposition of UN Sanctions," GIGA Working Papers, https://www.gigahamburg.de/en/system/files/publications/wp236_hirt.pdf.

28 Ibid.

29 United Nations Security Council, Report of the Monitoring Group on Somalia and Eritrea Pursuant to Security Council Resolution 2002 (2011), 2012.

30 Niamh Scallan, "Eritrean Government Using Consulate in Toronto to Impose Tax to Bankroll Military, un Charges," Toronto Star, 24 July 2012.

31 StewartBell, “'ItIsOurRight':Eritrea VowstoContinueTaxing Citizens in Canada Despite Warning from Ottawa," National Post, 21 September 2012, http://news.nationalpost.com/ news/canada/it-is-our-right-eritrea-vows-to-continuetaxing-citizens-in-canada-despite-warning-from-ottawa.

32 Tekie Fessehatzion, "Eritrea’s Remittance-Based Economy: Conjectures and Musings," Eritrean Studies Review 4, no. 2 (2005): 165-84.

33 "Regulations Implementing the United Nations Resolution on Eritrea," Canada Gazette, 2010, http://laws-lois.justice. gc.ca/eng/regulations/sor-2010-84/FullText.html.

34 Stewart Bell, "Canada Expelling Eritrean Diplomat for Using Consulate to Shake Down Citizens for 'National 
Defence," National Post, 29 May 2013, http://news.nationalpost.com/2013/05/29/canada-expelling-eritrean-diplomatfor-using-consulate-to-shake-down-citizens-for-nationaldefence/.

35 Gaim Kibreab, “The Eritrean Diaspora, the War of Independence, Post-Conflict (Re)-construction and Democratisation," in The Role of Diasporas in Peace, Democracy and Development in the Horn of Africa, ed. Ulf Johansson Dahre (Lund: Media-Tryck Sociologen Lunds universitet 2007), 97.

36 un Commission of Inquiry on Human Rights In Eritrea, Report of the Detailed Findings of the Commission of Inquiry on Human Rights in Eritrea, 5 June 2015, http://www.ohchr. org/Documents/HRBodies/HRcouncil/CoIEritrea/A_ HRC_29_CRP-1.pdf.

37 Hepner, "Religion, Nationalism, and Transnational Civil Society."

38 Tezare et al., Role of the Eritrean Diaspora in Peacebuilding and Development.

39 Tricia M. Redeker Hepner, Transnational Governance and the Centralization of State Power in Eritrea and Exile (London: Routledge, 2008).

40 UNHCR, "Sharp Increase in Number of Eritrean Refugees and Asylum-Seekers in Europe, Ethiopia and Sudan," 14 November 2014, http://www.unhcr.org/5465fea1381.html.

41 Tezare et al., Role of the Eritrean Diaspora.

42 Al-Ali, Black, and Koser, "Limits to 'Transnationalism."

43 “2011 National Household Survey: Data Tables," Statistics Canada, http://www12.statcan.gc.ca/nhs-enm/2011/dp-pd/ $\mathrm{dt}$-td/Rp-eng.cfm?lang=e\&apath $=3 \&$ detail $=0 \& \mathrm{dim}=0 \& \mathrm{fl}=$ a\&free $=0$ \&gc $=0$ \&gid $=0 \& g k=0 \& g r p=1 \& p i d=105396 \&$ prid $=0 \&$ ptype $=105277 \& \mathrm{~s}=0$ \&showall $=0$ \&sub $=0$ \&temporal $=2$ $013 \&$ theme $=95 \& v i d=0 \& v n a m e e \& v n a m e f$.

44 John W. Creswell, Qualitative Inquiry and Research Design: Choosing among Five Approaches (London: Sage, 2013).

45 Aaron Berhane, "Transnational Governance and Its Impact on the Settlement Process of Eritrean Refugees in Canada" (MA diss., Ryerson University, 2016).
46 Richard E. Boyatzis, Transforming Qualitative Information: Thematic Analysis and Code Development (Thousand Oaks, CA: Sage, 1998).

47 William Gibson and Andrew Brown, Working with Qualitative Data (London: Sage, 2009).

48 Earl R. Babbie and Lucia Benaquisto, Fundamentals of Social Research, 2nd Canadian ed. (Toronto: Nelson, 2009).

49 Lawrence Lam, From Being Uprooted to Surviving: Resettlement of Vietnamese-Chinese Boat People (Toronto: York Lanes, 1996); Danièle Joly, Haven or Hell?: Asylum Policies and Refugees in Europe (New York: Macmillan, 1996); and Ransford Danson, "From 'There' to 'Here': An Investigation of the Initial Settlement Experiences of Ethiopian and Somali Refugees in Toronto," GeoJournal 56, no. 1 (2002): 3-14.

50 Ibid.

51 Daniel Hiebert, "Precarious Housing and Hidden Homelessness among Refugee Asylum Seekers and Immigrants in Montreal, Toronto and Vancouver," Employment and Social Development Canada, 2011, http://www.esdc.gc.ca/eng/ communities/homelessness/research/kdp/immigrants/ precarious.shtml.

52 William Mishler and Richard Rose, Trust in Untrustworthy Institutions: Culture and Institutional Performance in Post-Communist Societies. (Glasgow: Centre for the Study of Public Policy, University of Stratchlyde, 1998); and Andrew Goldsmith, "Police Reform and the Problem of Trust," Theoretical Criminology 9, no. 4 (2005): 443-70.

Aaron Berhane is professor at George Brown College. The author may be contacted at aaron.berhane@georgebrown.ca.

Vappu Tyyskä is a professor in the Department of Sociology at Ryerson University. The author may be contacted atvtyyska@ ryerson.ca. 